\title{
Lactobacillus plantarum L67 glycoprotein protects against cadmium chloride toxicity in RAW 264.7 cells
}

\author{
Sooyeon Song, Sejong Oh, ${ }^{1}$ and Kye-Taek Lim ${ }^{1}$ \\ Division of Animal Science, Chonnam National University, 300 Yongbong-Dong, Gwang-ju 500-757, South Korea
}

\begin{abstract}
The food and water we consume may be contaminated with a range of chemicals and heavy metals, such as lead, cadmium, arsenic, chromium, and mercury by accumulation through the food chain. Cadmium is known to be one of the major components in cigarette smoke and can cause lesions in many organs. Some lactobacilli can bind and remove heavy metals such as cadmium, lead, and copper. However, the mechanisms of cadmium toxicity and inhibition by probiotics are not clear. In this study, we demonstrated that glycoprotein $(18 \mathrm{kDa})$ isolated from Lactobacillus plantarum L67 protected RAW 264.7 cells from expression of inflammation-related factors stimulated by cadmium chloride $(100 \mu M)$. Furthermore, we evaluated the cytotoxicity of cadmium using the MTT assay and intracellular $\mathrm{Ca}^{2+}$ using fluorescence, and assessed activities of activator protein kinase $\mathrm{C}(\mathrm{PKC}-\alpha)$, inducible nitric oxide synthase, activator protein (AP)-1, and mitogen-activated protein kinases using immunoblot. Our results indicated that glycoprotein isolated from L. plantarum L67 inhibited intracellular $\mathrm{Ca}^{2+}$ mobilization. It also significantly suppressed inflammatory factors such as AP-1 (c-Jun and c-Fos), mitogen-activated protein kinases (ERK, JNK, and p38), and inducible nitric oxide synthase. Our findings suggest that the 24-kDa glycoprotein isolated from L. plantarum L67 might be used as a food component for protection of inflammation caused by cadmium ion. Key words: activator protein (AP)-1, cadmium, glycoprotein, Lactobacillus plantarum, mitogenactivated protein kinases (MAPK)
\end{abstract}

\section{INTRODUCTION}

The recent growth in human industrial activity has led to exponential increases in the amounts of heavy

\footnotetext{
Received July 15, 2015.

Accepted September 7, 2015.

${ }^{1}$ Corresponding authors: soh@chonnam.ac.kr and ktlim@chonnam. ac.kr
}

metals released into the atmosphere, water, and soil (McConnell and Edwards, 2008). Cadmium (Cd) is a toxic heavy metal with a variety of adverse effects on the health of humans and animals. The risk of human exposure to heavy metal is increasing because of increasing Cd contamination of the food chain (Satarug et al., 2011). In recent years, many chronic Cd poisoning incidents have occurred due to inadequate protection from Cd-contaminated food and industrial material high-dose exposure (Fowler et al., 2011). Cadmium is present in almost all foods but the concentrations vary depending on the type of food and the level of environmental contamination (Saha et al., 2010). Food from plants generally contains higher concentrations of $\mathrm{Cd}$ than do meat, eggs, milk, dairy products, and fish (Buchauer. 1973; Olsson et al., 2002). Cadmium can cause lesions in different organs including kidney, testis, lung, liver, brain, bone, and blood. Inflammation, adenoma, and carcinoma are reportedly caused by exposure to $\mathrm{Cd}$ (Jarup et al., 1998; Nair et al., 2013).

The body's response to inflammation, adenoma, and carcinoma caused by $\mathrm{Cd}$ involves various factors. Intracellular $\mathrm{Ca}^{2+}$ has a role as secondary messenger in multiple signaling cascades (Batiza et al., 1996). Protein kinase C (PKC) is activated by intracellular $\mathrm{Ca}^{2+}$. When PKC is activated, it is translocated from the cytosol to cellular compartments (Nakashima, 2002). It has been reported that PKC $\alpha$ is activated by a variety of stimuli such as physiological stresses. The activated PKC $\alpha$ subsequently transfers the signal to the mitogen-activated protein kinase (MAPK) pathways (Nakashima, 2002); MAPK is one of the important molecules involved in Cd-induced neurotoxicity (Kim et al., 2005; Chen et al., 2011; Thévenod and Lee, 2013). The MAPK are composed of a signaling cascade of serine-threonine kinases. They include extracellular signal-regulated kinase (ERK), p38, and cJun $\mathrm{NH}_{2}$-terminal kinase (JNK). Observations suggest that MAPK contribute to inflammatory responses and neuronal death in neurodegenerative diseases, and that activated MAPK contribute to cell proliferation and carcinogenesis (Ito et al., 1998; Chang and Karin, 2001; Kim and Choi, 2010). 
Activator protein (AP)-1 is a transcriptional factor, as well as a redox-sensitive oncogenic protein, and it controls the expression of cell growth mediators. It is a heterodimer consisting of the of Jun and Fos proteins (Kouzarides and Ziff, 1988), and is associated with malignant transformation, tumor promotion, and carcinogenic development. It regulates expression of inducible nitric oxide synthase (iNOS) pro-inflammatory factors (Lee and Lim, 2011).

Lactic acid bacteria have a long history as probiotics (Fernández et al., 2015). Several reports describe the various effects of Lactobacillus species including antitumor, anticoagulant, antiviral, immune regulator, and antiinflammatory, antidiabetic, and antioxidant or free radical scavenging activity (Hong et al., 2014; Song et al., 2015a,b). Additionally, studies have revealed that some Lactobacillus, such as Lactobacillus rhamnosus, Lactobacillus plantarum, and Lactobacillus brevis, can bind and remove heavy metals such as cadmium, lead, and copper in vitro (Halttunen et al., 2008; Mrvcic et al., 2009). We recently reported that membrane proteins (12 and $15 \mathrm{kDa}$ ) isolated from L. plantarum L67 induced apoptosis in human colorectal adenocarcinoma cells (Song et al., 2015b). Glycoproteins of some Lactobacillus have been known to have beneficial effects including regulating immature dendritic cells, modulating T-cell functions, and inhibiting the adherence of pathogens in intestines (Rhee and Park, 2001; JohnsonHenry et al., 2007; Konstantinov et al., 2008).

Therefore, the purpose of this study was to investigate the inhibitory effect of glycoprotein $(18 \mathrm{kDa})$ isolated from L. plantarum L67 (L67 protein) in cadmium chloride-treated RAW 264.7 cells (a murine macrophage line). We also attempted to determine the possible mechanism of factors mediated with inflammation, cell proliferation, and cell cycle control. Toxicity of $\mathrm{Cd}$, intracellular $\mathrm{Ca}^{2+}$ mobilization, and activity of PKC were measured using the MTT assay and a fluorescence method, respectively. The expression of MAPK and AP-1 (c-Jun and c-Fos) was evaluated using Western blotting. Finally, we demonstrated that L. plantarum L67 is a starter culture strain with a protective effect against Cd toxicity.

\section{MATERIALS AND METHODS}

\section{Chemical}

All plastic materials were purchased from Falcon Labware (Becton Dickinson, Franklin Lakes, NJ). Penicillin G and streptomycin were obtained from Sigma (St. Louis, MO). Fetal bovine serum (FBS) and RPMI1640 medium were purchased from Gibco BRL (Grand
Island, NY). Other chemicals and reagents were of the highest analytical grade available.

\section{Bacteria}

Lactobacillus plantarum L67 (GenBank accession number: KR336551) strains from infant feces were selected according to Song et al. (2014). For identification of $L$. plantarum L67, the biochemical properties were first examined using an API 50CHL kit (bioMérieux, Marcy l'Etoile, France) and then by $16 \mathrm{~S}$ rDNA sequencing. Lactobacillus plantarum L67 was grown in de Man, Rogosa, and Sharpe (MRS) broth (BD Difco, Le Pont de Claix, France) at $37^{\circ} \mathrm{C}$ for $18 \mathrm{~h}$. The bacterial cells were separated by centrifugation at $3,000 \times g$ for 15 min at room temperature. Subsequently, the precipitated cells were washed twice with sterile saline $(0.85 \%$ sodium chloride). One milliliter of $10 \%$ skim milk was added to the sediments and the suspensions were stored at $-80^{\circ} \mathrm{C}$ until use.

\section{Growth of L. plantarum L67 in Skim Milk and Preparation of Glycoprotein}

Two hundred milliliters of skim milk broth was inoculated with $L$. plantarum L67 (1\%) and incubated at $37^{\circ} \mathrm{C}$. Cells were serially diluted with $1 \%$ peptone water and viable cells were counted every $3 \mathrm{~h}$ for $24 \mathrm{~h}$.

For protein preparation, $10 \mathrm{~mL}$ of cultures were obtained after $18 \mathrm{~h}$ at $37^{\circ} \mathrm{C}$. Pellets were collected by centrifugation $\left(12,000 \times g, 4^{\circ} \mathrm{C}\right)$ and washed 3 times using sterile deionized water. The washed cells were resuspended in $10 \mathrm{~g} / \mathrm{L}$ SDS solution and boiled for 10 min. The supernatants were harvested after centrifugation $\left(12,000 \times g, 4^{\circ} \mathrm{C}, 15 \mathrm{~min}\right)$ and dialyzed against distilled water at $4^{\circ} \mathrm{C}$. The supernatants were dried with a freeze-dryer and stored at $-70^{\circ} \mathrm{C}$. Protein concentrations were measured using the Bradford assay (Bradford, 1967). To confirm the results, SDS-PAGE was performed with the protein $(100 \mathrm{mg} / \mathrm{mL})$ containing $0.1 \%$ SDS, using a $14 \%$ polyacrylamide mini-gel and a Mini-Protean II electrophoresis cell (Bio-Rad, Hercules, CA) at $110 \mathrm{~V}$ and $30 \mathrm{~mA}$. The L67 protein was confirmed by staining with Schiff's reagent (Neville and Glossmann, 1974).

\section{Cell Culture and Cytotoxicity}

Murine RAW 264.7 cells were incubated in RPMI-1640 medium containing $10 \% \mathrm{FBS}, 100 \mathrm{U} / \mathrm{mL}$ penicillin, and $100 \mathrm{mg} / \mathrm{mL}$ streptomycin in an atmosphere containing $5 \% \mathrm{CO}_{2}$ at $37^{\circ} \mathrm{C}$. The medium was renewed twice per 
week. Cells $\left(1 \times 10^{6}\right.$ cells $\left./ \mathrm{mL}\right)$ were distributed into 35 -mm culture dishes or 96-well flat-bottomed plates. The final volumes were $2 \mathrm{~mL} /$ dish in the $35-\mathrm{mm}$ culture dishes and $100 \mu \mathrm{L} /$ well in the 96-well flat-bottomed plates. The cytotoxicity of cadmium chloride and inhibitory effect of L67 total protein were determined by the MTT assay (Patton et al., 1989).

\section{Detection of Intracellular $\mathrm{Ca}^{2+}$ Mobilization}

Intracellular calcium was determined as described previously (Kimata et al., 1999). Briefly, cells were treated with L67 total protein $(5,10,20,50$, and 100 $\mu \mathrm{g} / \mathrm{mL}$ ) for $12 \mathrm{~h}$. Cells were rinsed with a bath solution $\left(140 \mathrm{mmol}\right.$ of $\mathrm{NaCl}, 5 \mathrm{mmol}$ of $\mathrm{KCl}, 1 \mathrm{mmol} \mathrm{CaCl}_{2}$, $0.5 \mathrm{mmol}$ of $\mathrm{MgCl}_{2}, 10 \mathrm{mmol}$ of glucose, $5.5 \mathrm{mmol}$ of HEPES, $\mathrm{pH} 7.5$ ) and then preincubated in bath solution containing $1 \mu \mathrm{mol}$ of Fura-2/AM (Molecular Probes, Eugene, OR) with $5 \% \mathrm{CO}_{2}$ at $37^{\circ} \mathrm{C}$ for $45 \mathrm{~min}$ with gentle shaking. Cells were treated with $100 \mu M$ cadmium chloride for $3 \mathrm{~h}$. Fluorescence intensity was measured at an emission wavelength of $510 \mathrm{~nm}$ and excitation wavelengths of 340 and $380 \mathrm{~nm}$ using a fluorescent microplate reader (Dual Scanning SpectraMax, Molecular Devices, Sunnyvale, CA).

\section{Membrane, Cytosolic, and Whole-Protein Extract from RAW 264.7 Cells}

The cells were rinsed twice with PBS after removing the medium and scraped in $300 \mu \mathrm{L}$ of buffer $\mathrm{A}[20$ $\mathrm{m} M$ Tris- $\mathrm{HCl}, \mathrm{pH} 7.5,0.25 M$ sucrose, $2 \mathrm{~m} M$ EDTA, and $2 \mathrm{~m} M$ EGTA] containing a protease inhibitor cocktail (Boehringer, Mannheim, Germany). The cells were sonicated and centrifuged for $1 \mathrm{~h}$ at 10,000 $\times g$ to sediment all membranes and the insoluble cytoskeletal components. The supernatant was designated as the cytosolic fraction. The membrane proteins in the pellet were extracted with buffer B $(20 \mathrm{~m} M$ Tris-HCl, pH 7.5, $1 \%$ Nonidet P-40 (Sigma), $150 \mathrm{~m} M \mathrm{NaCl}, 1$ $\mathrm{m} M$ EGTA, and $1 \mathrm{~m} M$ EDTA) containing a protease inhibitor cocktail (Boehringer) on ice for $30 \mathrm{~min}$ and centrifuged for $15 \mathrm{~min}$ at $100,000 \times \mathrm{g}$ at $4^{\circ} \mathrm{C}$. The supernatant was saved as the detergent-soluble membrane fraction. Then, either nucleic protein extract for the immunoblotting of AP-1 (c-Jun and c-Fos) and proliferating cell nuclear antigen (PCNA) or whole cellular protein extract for the immunoblotting of MAPK (ERK, p38, and JNK) was isolated from RAW 264.7 cells as previously described (Oh and Lim, 2008). The amount of protein was measured via the method developed by Lowry et al. (1951) and cellular proteins were stored at $-70^{\circ} \mathrm{C}$ before use.

\section{Western Blot Analysis}

Cellular proteins were separated on a $10 \%$ polyacrylamide mini-gel at $100 \mathrm{~V}$ for $2 \mathrm{~h}$ at room temperature using a Mini-Protein II Electrophoresis Cell (Bio-Rad). After electrophoresis, the proteins were transferred to nitrocellulose membranes (Millipore, Bedford, MA). The membranes were subsequently incubated for $2 \mathrm{~h}$ at room temperature with primary antibodies $(\mathrm{PKC} \alpha$, ERK, phosphor-ERK, JNK, phospho-JNK, and AP-1 (c-Fos and c-Jun) in Tris-buffered saline-Tween (TBST) solution. After washing 3 times with TBS-T, the membranes were incubated for $1 \mathrm{~h}$ at room temperature with horseradish peroxidase-conjugated goat anti-mouse IgG and anti-rabbit IgG (1:10,000; Cell Signaling Technology, Danvers, MA) in TBS-T solution. The resulting protein bands were visualized by enhanced chemiluminescence (Amersham Pharmacia Biotech, Bristol, UK). The results of the immunoblot assay were calculated as relative intensity using Scion imaging software (Scion Image Beta 4.02, Scion, Frederick, MD).

\section{Statistical Analysis}

All experiments were carried out in triplicate and data were expressed as the means \pm standard errors $(\mathrm{n}=6)$. The statistical significance of differences in results obtained under different experimental conditions was analyzed by 2-way ANOVA followed by Tukey's post hoc test for individual treatments.

\section{RESULTS}

\section{Growth of L. plantarum L67 in Skim Milk and Isolation of Glycoprotein}

As a first step to use L. plantarum L67 as starter culture strain, we constructed a growth curve for $L$. plantarum L67 in skim milk at $37^{\circ} \mathrm{C}$. Figure 1 shows the growth curve of L. plantarum L67 in skim milk at $37^{\circ} \mathrm{C}$. The L. plantarum L67 on the skim milk broth at $37^{\circ} \mathrm{C}$ reached $8.0 \log \mathrm{cfu} / \mathrm{mL}$ after $6 \mathrm{~h}$, and $8.7 \log \mathrm{cfu} /$ $\mathrm{mL}$ after $12 \mathrm{~h}$. After $24 \mathrm{~h}$, viable cells reached $8.3 \mathrm{log}$ $\mathrm{cfu} / \mathrm{mL}$.

For the glycoprotein isolated from L. plantarum L67, the gel was stained with Schiff's reagent. Figure 2 indicates that the glycoprotein isolated from L. plantarum L67 had a molecular weight of $18 \mathrm{kDa}$.

\section{Cytotoxicity of $\mathrm{Cd}$ and Anticytotoxicity Effect of L67 Protein}

As shown in Figure 3, when the RAW 264.7 cells were treated with $100 \mu M \mathrm{Cd}$ for $3 \mathrm{~h}$, the half-maximal 


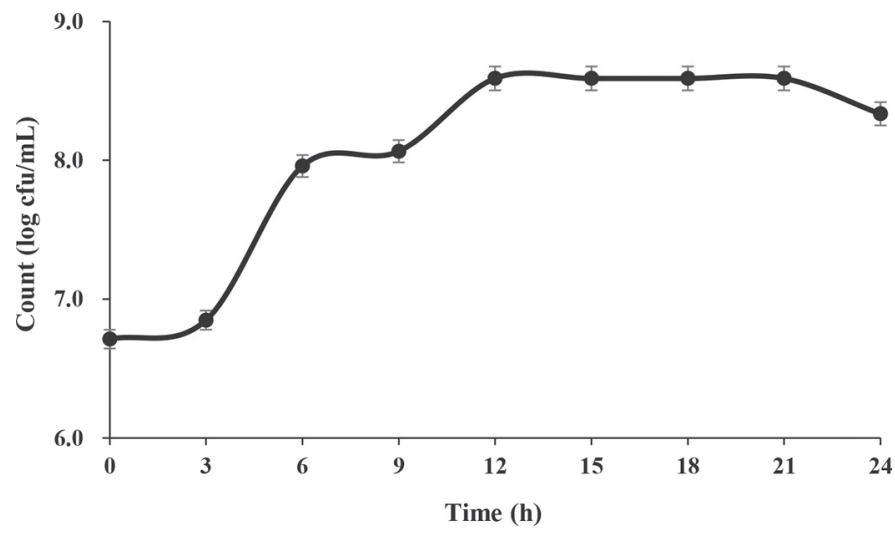

Figure 1. Growth curve of Lactobacillus plantarum L67 on skim milk. Two hundred milliliters of skim milk broth was inoculated with L. plantarum L67 $(1 \%)$ and incubated at $37^{\circ} \mathrm{C}$. The cells were serially diluted with $1 \%$ peptone water to count viable cells every $3 \mathrm{~h}$ for $24 \mathrm{~h}$. Error bars indicate SE.

inhibitory concentration $\left(\mathrm{IC}_{50}\right)$ of RAW 264.7 cells was $100 \mu M$. However, when the RAW 264.7 cells were treated with $\mathrm{Cd}(100 \mu M)$ after pretreatment with L67 protein $(5,10,20,50$, and $100 \mathrm{~g} / \mathrm{mL})$, survivability increased significantly in a dose-dependent manner, compared with that without pretreatment with L67 protein. For example, the survivability of Cd-treated RAW 264.7 cells was increased by $64,80,88,90$, and $98 \%$ following pretreatment with $5,10,20,50$, and 100 $\mu \mathrm{g} / \mathrm{mL}$ of $\mathrm{L} 67$ protein in the presence of $\mathrm{Cd}(100 \mu M)$, respectively.

\section{Inhibitory Effect of L67 Protein on Intracellular $\mathrm{Ca}^{2+}$ Level}

We examined the involvement of intracellular $\mathrm{Ca}^{2+}$ level in Cd-treated RAW 264.7 cells. As shown in Figure 4 , intracellular $\mathrm{Ca}^{2+}$ level increased by 1.15 -fold when cells were treated with $\mathrm{Cd}$ compared with the control. However, with the L67 protein treatment, $\mathrm{Cd}$ induced an increase of intracellular $\mathrm{Ca}^{2+}$ in a concentrationdependent manner. Intracellular $\mathrm{Ca}^{2+}$ concentration underwent a 0.08 -fold reduction following pretreatment with $\mathrm{L} 67$ protein $(100 \mu \mathrm{g} / \mathrm{mL})$ in the presence of $\mathrm{Cd}$, compared with the Cd treatment without L67 pretreatment.

\section{Inhibitory Effect of L67 Protein on Activity of PKCa in Cd-Treated RAW 264.7 Cells}

As shown in Figure 5, when cells were treated with $\mathrm{Cd}$, translocation of PKC $\alpha$ from the cytosol to the membrane was induced at $3 \mathrm{~h}$ after treatment. Treat- ment with $\mathrm{Cd}(100 \mu M)$ resulted in a 0.23 -fold reduction of band intensity of PKC $\alpha$ in the cytosolic extract, whereas intensity increased by 2.59-fold in the membrane extract, compared with the controls. However, when the cells were treated with $\mathrm{Cd}$ after pretreatment with L67 protein, PKC $\alpha$ translocation was inhibited in the Cd-treated RAW 264.7 cells in a concentrationdependent manner. Relative intensities of PKC $\alpha$ band in the membrane fraction underwent 0.37-and 0.54-fold reductions with a pretreatment of L67 at 50 and 100 $\mu \mathrm{g} / \mathrm{mL}$, respectively.

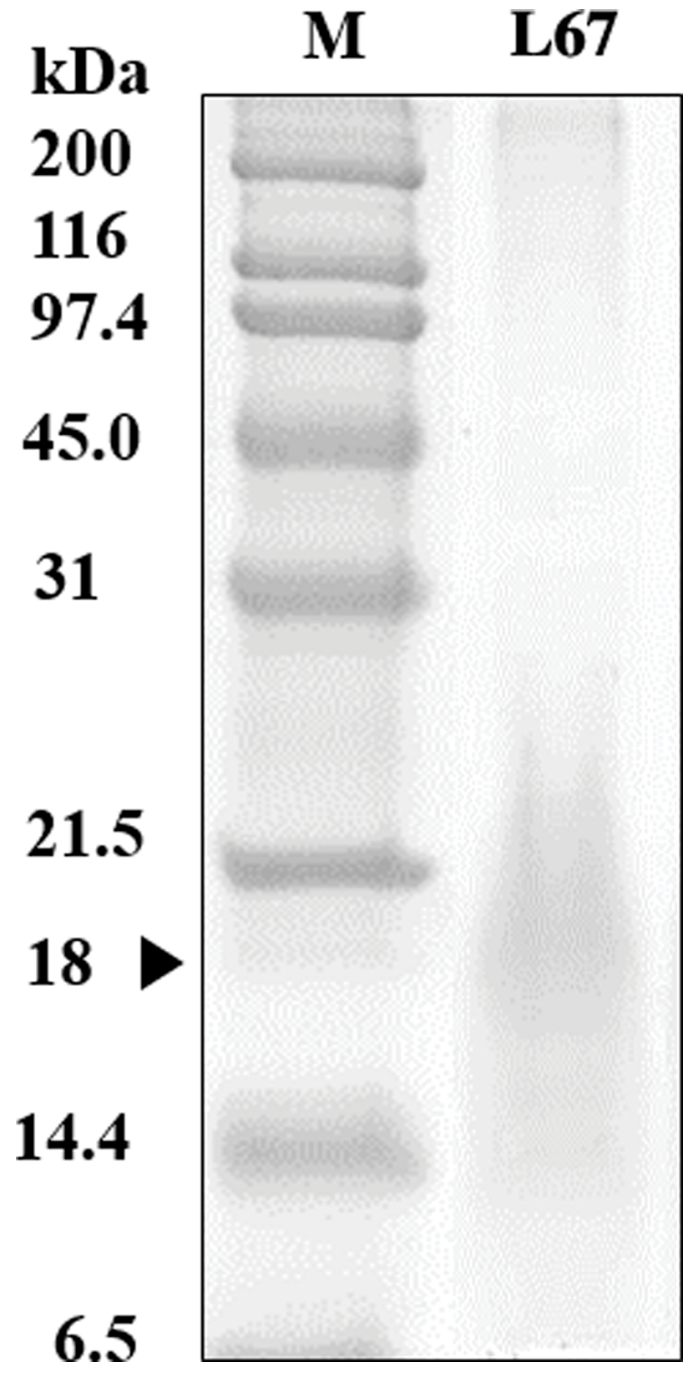

Figure 2. Identification of the L67 protein from Lactobacillus plantarum. Electrophoresis was performed on 14\% acrylamide gel and the gel stained with Schiff's reagent for glycoprotein isolated from L. plantarum $\mathrm{L} 67 . \mathrm{M}=$ marker; $\mathrm{L} 67=$ glycoprotein isolated from $L$. plantarum L67. 
1816

(A)

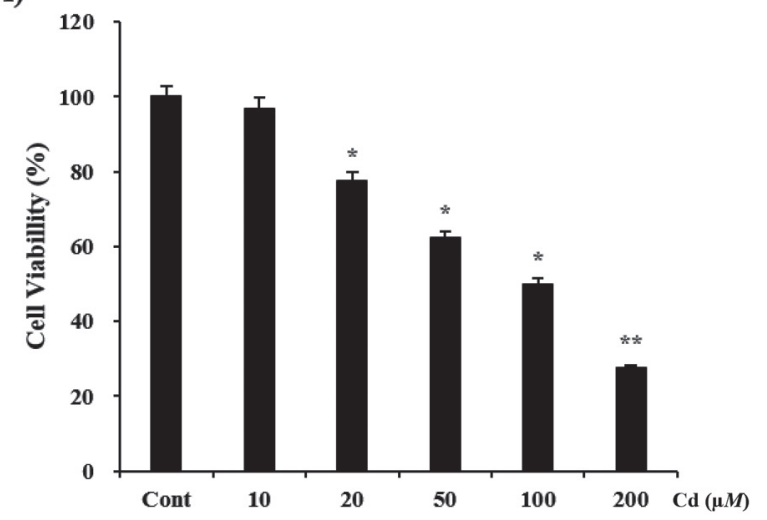

(B)

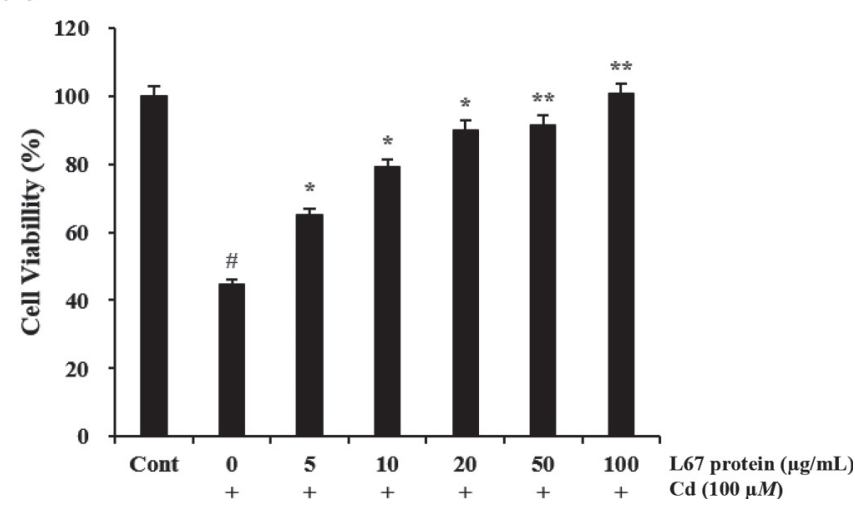

Figure 3. Cytotoxicity of $\mathrm{Cd}$ and anticytotoxicity effect of L67 protein on $\mathrm{Cd}(100 \mu M)$-treated RAW 264.7 cells. The cytotoxicity of cadmium chloride measured by MTT [3-(4,5-dimethylthiazol2-yl)-2,5-diphenyltetrazolium bromide assay was dose-dependent (A), as was anticytotoxicity effect following pretreatment with L67 protein (5-100 $\mu \mathrm{g} / \mathrm{mL})(B)$. All data represent means \pm SE from triplicates. \#Significant difference between the treatment and control groups $(P$ $<0.05) ;{ }^{*}$ and ${ }^{* *}$ significant difference between $\mathrm{Cd}$ treatment and L67 protein pretreatment in the presence of $\mathrm{Cd}\left({ }^{*} P<0.05,{ }^{* *} P<0.01\right)$. Cont $=$ control

\section{Inhibitory Effect of L67 Protein on Expression of iNOS in Cd-Treated RAW 264.7 Cells}

As shown in Figure 5, pretreatment with L67 protein inhibited expression of iNOS in Cd-stimulated RAW 264.7 cells. For instance, in cells that were treated with $\mathrm{Cd}$, expression of iNOS was significantly increased compared with the control. However, when cells were treated with a pretreatment of L67 protein $(5-100 \mu \mathrm{g} /$ $\mathrm{mL}$ ), activity of iNOS decreased significantly in a dosedependent manner (Figure 6). The relative intensities of iNOS were increased 2.27-fold after treatment with Cd compared with those in the control. However, such activity underwent a 0.88 -fold reduction for iNOS after the treatment with $\mathrm{Cd}$ and pretreatment of $\mathrm{L} 67$ protein $(100 \mu \mathrm{g} / \mathrm{mL})$ compared with $\mathrm{Cd}$ treatment alone.

\section{Inhibitory Effect of L67 Protein on Phosphorylation of ERK, JNK, and p38 in Cd-Treated RAW 264.7 Cells}

To determine whether pretreatment with L67 protein inhibits ERK and JNK phosphorylation in the Cdtreated RAW 264.7 cells, we assessed ERK and JNK phosphorylation after treatment with Cd for $3 \mathrm{~h}$. Activities of both JNK and ERK were increased by treatment with $100 \mu M$ Cd compared with the controls (Figure 7). Relative band intensities of ERK and JNK underwent 10-and 21-fold increases, respectively, compared with treatment with $\mathrm{Cd}$ treatment alone. However, when the cells were treated with $\mathrm{Cd}$ after pretreatment of L67 protein $(5,10,20,50$, and $100 \mu \mathrm{g} / \mathrm{mL})$, the relative band intensities were reduced in a dose-dependent manner. When the cells were treated with $\mathrm{Cd}(100 \mu M)$ after pretreatment with $\mathrm{L} 67$ protein $(100 \mu \mathrm{g} / \mathrm{mL})$, the band intensities of ERK and JNK were significantly reduced by 7 - and 21 -fold, respectively, compared with the $\mathrm{Cd}$ treatment alone.

\section{Inhibitory Effect of L67 Protein on Transcriptional Factor AP-1 in Cd-Treated RAW 264.7 Cells}

We evaluated the effects of L67 protein on activation of AP-1 (c-Jun and c-Fos) using Western blotting analysis. When the cells were treated with 100 $\mu M \mathrm{Cd}$ for $3 \mathrm{~h}$, AP-1 activity was markedly increased compared with the control. However, when the cells were pretreated with $\mathrm{L} 67$ protein $(50$ and $100 \mu \mathrm{g} / \mathrm{mL})$

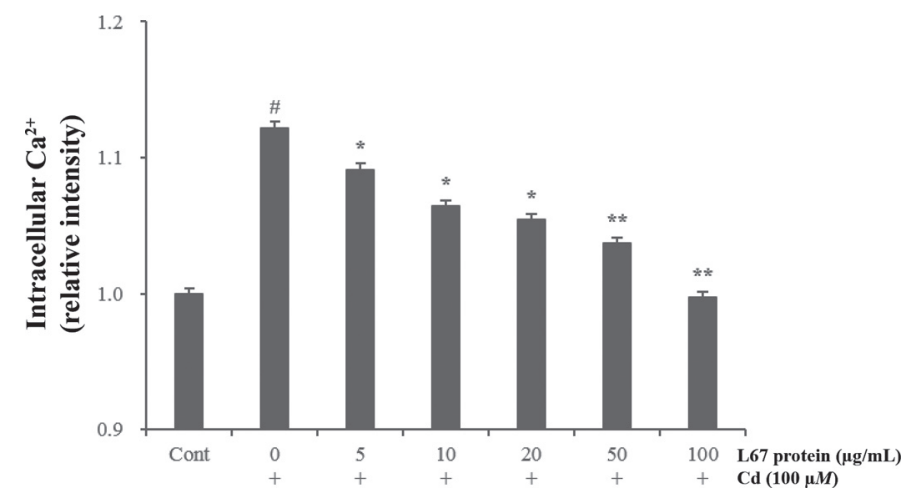

Figure 4. Inhibitory effect of L67 protein from Lactobacillus plantarum on mobilization of intracellular $\mathrm{Ca}^{2+}$ in Cd-treated RAW 264.7 cells. The cells were treated with $100 \mu M \mathrm{Cd}$ without or with pretreatment with L67 protein $(5,10,20,50$, and $100 \mu \mathrm{g} / \mathrm{mL})$. Changes in intracellular $\mathrm{Ca}^{2+}$ concentration were monitored with Fura-2/AM, as described in the Materials and Methods. Data were expressed as the absolute intensity of $\mathrm{Ca}^{2+}$ fluorescence and are shown as means $\pm \mathrm{SE}$ from triplicates $(\mathrm{n}=9)$. \#Significant difference between the treatment and control groups $(P<0.05) ; *$ and ${ }^{* *}$ significant difference between $\mathrm{Cd}$ treatment and $\mathrm{L} 67$ protein pretreatment in the presence of $\mathrm{Cd}\left({ }^{*} P\right.$ $\left.<0.05,{ }^{* *} P<0.01\right)$. Cont $=$ control. 
(A)
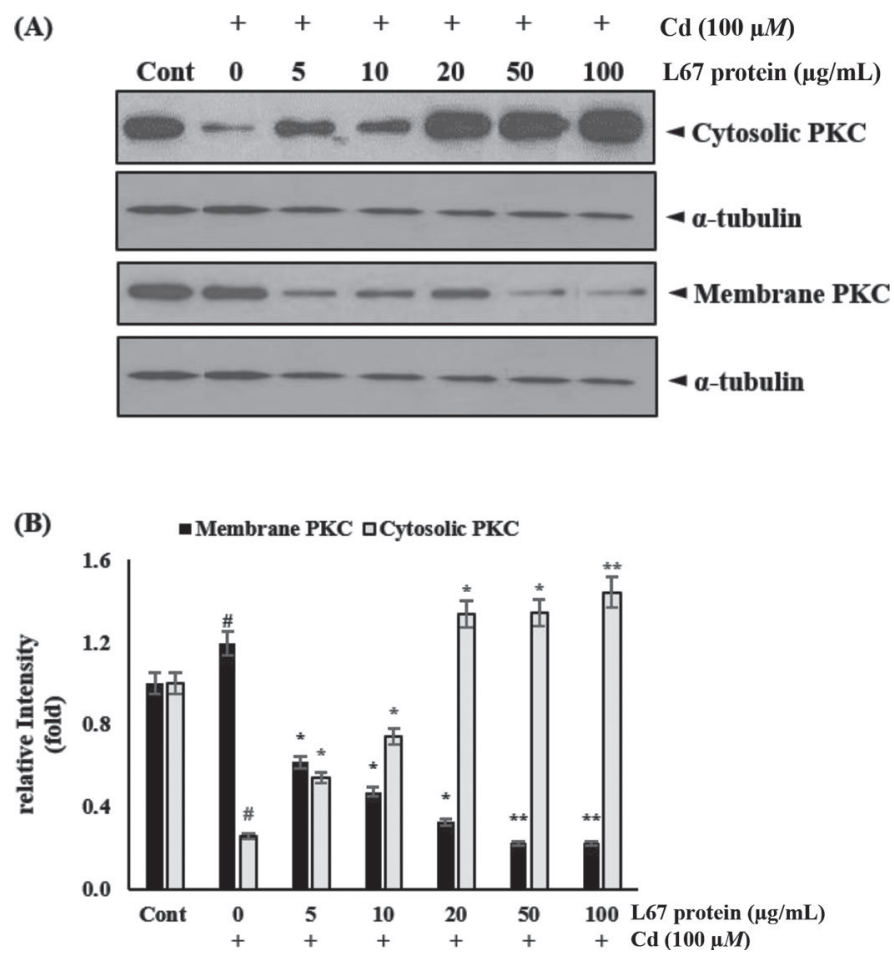

Figure 5. Inhibitory effect of L67 protein from Lactobacillus plantrum on the activity of protein kinase C (PKC) in Cd-treated RAW 264.7 cells. The cells were treated with $\mathrm{Cd}(100 \mu M)$ alone or pretreated with $\mathrm{L} 67$ protein $(5,10,20,50$, and $100 \mu \mathrm{g} / \mathrm{mL})$ and $\mathrm{Cd}$ for $3 \mathrm{~h}$. The relative intensities of bands were calculated using Scion Imaging Software (Scion Image Beta 4.02; Scion, Frederick, MD). Data were represented as absolute intensity and expressed as means $\pm \mathrm{SE}$ from triplicates $(\mathrm{n}=9)$. \#Significant difference between treatments and controls $(P<0.05) ;{ }^{*}$ and ${ }^{* *}$ significant difference between $\mathrm{Cd}$ treatment and $\mathrm{L} 67$ protein pretreatment in the presence of $\mathrm{Cd}\left({ }^{*} P<\right.$ $\left.0.05,{ }^{* *} P<0.01\right)$. Cont $=$ control.

and treated with $100 \mu M \mathrm{Cd}$, the activity of AP-1 was significantly reduced in a concentration-dependent manner compared with the $\mathrm{Cd}$ treatment alone. The relative intensities of AP-1 (c-Jun and c-Fos) were augmented 10-fold and 76-fold following $100 \mu \mathrm{M} \mathrm{Cd}$ treatment alone compared with the controls. However, when the cells were pretreated with L67 protein (100 $\mu \mathrm{g} / \mathrm{mL}$ ) before treatment with $\mathrm{Cd}$, the activities of AP-1 (c-Jun and c-Fos) were diminished by 6 -fold and 65-fold, respectively, compared with $\mathrm{Cd}$ alone (Figure 8). However, when the cells were pretreated with L67 protein $(100 \mu \mathrm{g} / \mathrm{mL})$ in the presence of $\mathrm{Cd}$, the activities of AP-1 (c-Jun and c-Fos) were reduced on treatment with L67 protein $(5,10,20,50$, and $100 \mu \mathrm{g} / \mathrm{mL})$ in a dose-dependent manner.

\section{DISCUSSION}

Cadmium, a well-known carcinogen and immunotoxin that is commonly found in cigarette smoke and indus-
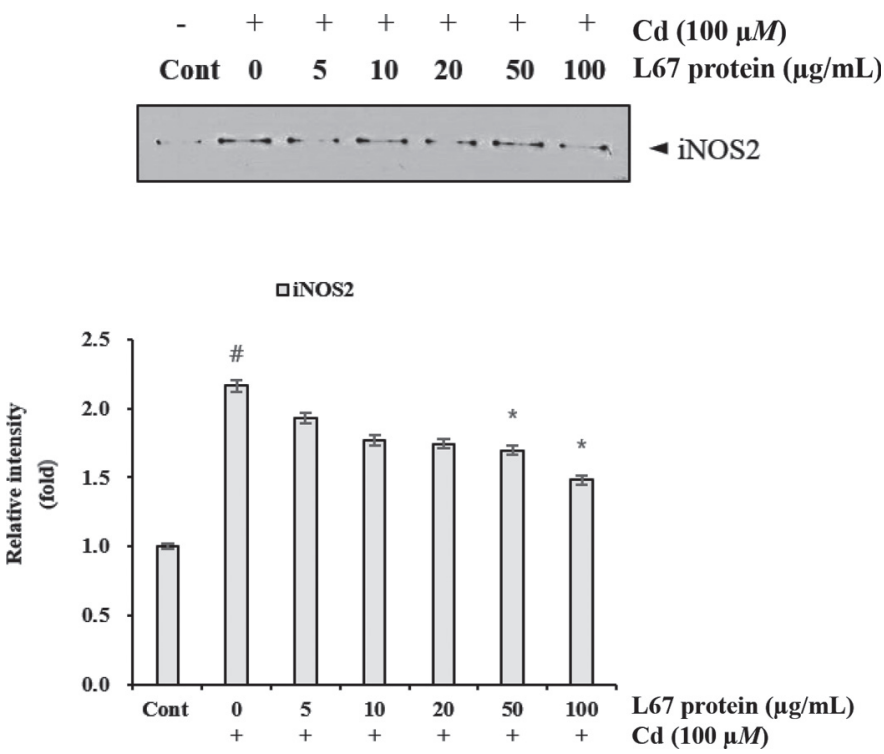

Figure 6. Inhibitory effect of L67 protein from Lactobacillus plantarum on expression of inducible nitric oxide synthase (iNOS) in Cdtreated RAW 264.7 cells. The cells were treated with Cd $(100 \mu M)$ alone or pretreated with the L67 protein $(5,10,20,50$, and $100 \mu \mathrm{g}$ / $\mathrm{mL}$ ) and $\mathrm{Cd}$ for $3 \mathrm{~h}$. The relative intensities of bands were calculated using Scion Imaging Software (Scion Image Beta 4.02; Scion, Frederick, MD). Data were represented as absolute intensity and expressed as means \pm SE from triplicates $(\mathrm{n}=9)$. \#Significant difference between treatments and controls $(P<0.05)$; *significant difference between $\mathrm{Cd}$ treatment and L67 protein pretreatment in the presence of $\mathrm{Cd}(P<$ 0.05). Cont $=$ control.

trial effluent, poses a toxicity risk for humans because of its presence in the food chain. In this investigation, we attempted to determine whether L67 protein from $L$. plantarum would protect RAW 264.7 cells from expression of inflammation-related factors stimulated by cadmium chloride. As a first step to use L. plantarum L67 as the starter culture strain, we constructed a growth curve for L. plantarum L67 in skim milk at $37^{\circ} \mathrm{C}$. This strain can be used as starter culture and has probiotic potential. To determine the cytotoxicity of $\mathrm{Cd}$ in RAW 264.7 cells, we used the MTT assay. The results indicated an $\mathrm{IC}_{50}$ of $100 \mu M$ after a 3 -h treatment. We also determined survivability of RAW 264.7 cells pretreated with L67 protein at different concentrations $(5-100 \mu \mathrm{g} /$ $\mathrm{mL}$ ). The results showed that pretreatment with L67 protein improved the survivability of Cd-treated RAW 264.7 cells (Figure 3).

Cadmium can disrupt signaling cascades that lead to a variety of toxic effects because of the similarities between $\mathrm{Cd}^{2+}$ and calcium ion $\left(\mathrm{Ca}^{2+}\right)$. Many studies have reported how $\mathrm{Cd}$ can effect changes in calcium signaling pathways and their resultant toxic effects. Differences in calcium signal duration and amplitude and subcellular location of the stimulus can affect processes such as cell division, cell motility, muscle contraction, meta- 
(A)

\begin{tabular}{|c|c|c|c|c|c|c|c|}
\hline Cont & 0 & $\begin{array}{l}+ \\
5\end{array}$ & $\begin{array}{c}+ \\
10\end{array}$ & $\begin{array}{l}+ \\
20\end{array}$ & $\begin{array}{l}+ \\
50\end{array}$ & $\begin{array}{c}+ \\
100\end{array}$ & $\begin{array}{l}\text { Cd }(100 \mu M) \\
\text { L67 protein }(\mu \mathrm{g} / \mathrm{mL})\end{array}$ \\
\hline & & & & & & -1 & Phospho-ERK \\
\hline
\end{tabular}

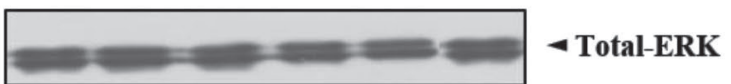

(B)

$\begin{array}{cccccccl}- & + & + & + & + & + & + & \operatorname{Cd}(100 \mu M) \\ \text { Cont } & 0 & 5 & 10 & 20 & 50 & 100 & \text { L67 protein }(\mu \mathrm{g} / \mathrm{mL})\end{array}$

- P-ERK

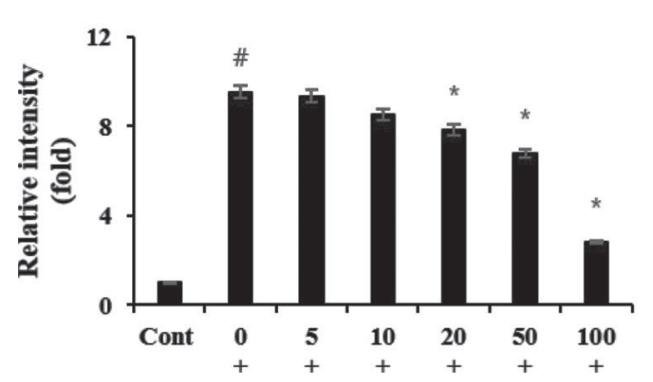

口P-JNK

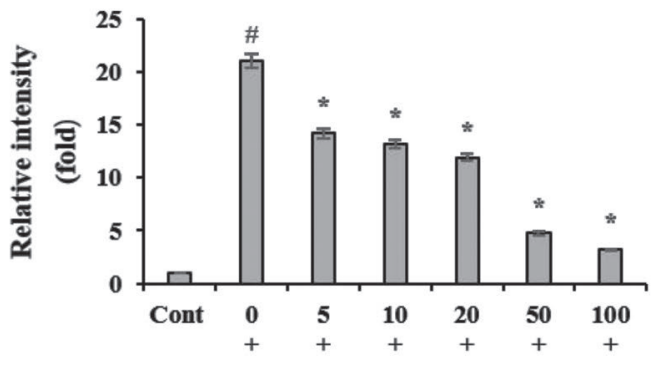

Figure 7. Inhibitory effect of L67 protein from Lactobacillus plantarum on phosphorylation (Phospho- or P) of extracellular signal-regulated kinase (ERK) and c-Jun $\mathrm{NH}_{2}$-terminal kinase (JNK) in Cd-treated RAW 264.7 cells. The cells were treated with Cd $(100 \mu M)$ for $3 \mathrm{~h}$ alone or pretreated with L67 protein $(5,10,20,50$, and $100 \mu \mathrm{g} / \mathrm{mL})$. The relative intensities of bands were calculated with Scion Imaging Software (Scion Image Beta 4.02; Scion, Frederick, MD). Data were represented as absolute intensities and expressed as means $\pm \mathrm{SE}$ from triplicates $(\mathrm{n}=9)$. \#Significant difference between the treatment and control groups $(P<0.05)$; *significant difference between Cd treatment and L67 protein in the presence of $\mathrm{Cd}(P<0.05)$. Cont $=$ control.

bolic activity, and apoptosis (Cheung, 1988; Roderick and Cook, 2008). This study showed that intracellular $\mathrm{Ca}^{2+}$ was released by treatment with $\mathrm{Cd}$ alone in RAW 264.7 cells, whereas L67 protein inhibited the amounts of $\mathrm{Ca}^{2+}$ in the presence of Cd (Figure 4). Thus, changes in calcium signaling caused by $\mathrm{Cd}$ were normalized or inhibited by pretreatment with L67 protein. In addition, the change in $\mathrm{Ca}^{2+}$ amount was closely related to mobilization of PKC (activation) from the cytosol to inside the cell membrane, because PKC activation depends on $\mathrm{Ca}^{2+}$. In this study, the L67 protein suppressed the translocation (activation) of PKC $\alpha$ from the cytosol to the cell membrane in Cd-treated RAW 264.7 cells (Figure 5). Activation of PKC plays a critical role in cell survival, proliferation, and tumor promotion (Zheng et al., 2010). The activation of the ERK1/2 and JNK pathways is mediated by PKC isoforms (DobkinBekman et al., 2010).

Inducible NOS plays important roles as a regulator of inflammatory reactions. Activity of iNOS and overproduction of nitric oxide (NO) are related to increased risk of many diseases (Chung et al., 2007). Inducible NOS is an inflammation and pro-tumor mediator, but it also causes the overproduction of nitric oxide (Chung et al., 2007). Low levels of NO usually regulate many physiological processes, whereas over- production of $\mathrm{NO}$, as a free radical, increases oxidative stress and participates in pathogenesis (Lee and Lim, 2011). Synthesis of iNOS is significantly induced in macrophages from cadmium-treated mice (Ramirez and Gimenez, 2003). In the current study, iNOS activity was increased by $\mathrm{Cd}$ treatment, whereas L67 protein inhibited iNOS activity in Cd-stimulated RAW 264.7 cells. (Figure 6 ).

Mitogen-activated protein kinases are essential components of intracellular signal transduction and are activated by phosphorylation in response to a variety of extracellular stimuli including growth factors, cytokines, and environmental stress (Ito et al., 1998; Chang and Karin, 2001; Kim and Choi, 2010). Cadmium toxicity upregulates several genes in MAPK pathways. The activation of MAPK can play an important role in Cdinduced cellular apoptosis (Tzirogiannis et al., 2003; Scholz-Ahrens et al., 2007; Kruger et al., 2009). Zhai et al. (2014) showed that co-treatment with Cd and Lactobacillus plantarum reverses some of these altered gene expressions in the MAPK pathway, indicating that the antioxidative stress effect of Lactobacillus plantarum may be related to regulation of these signal transduction pathways, which in turn decreases production of reactive oxygen species and prevents Cd-induced cellular apoptosis (Zhai et al., 2014). Wang et al. (2014) 
found that ERK, p38, and JNK were activated by Cd in neuronal cells in vitro and in vivo, and that activation of ERK or JNK promoted cell death, whereas activation of p38 inhibited cell death. As shown in Figure 7, our findings also demonstrated that phosphorylated ERK and JNK were strongly expressed by treatment with $\mathrm{Cd}$ and inhibited by pretreatment with L67 protein. The activation of the ERK and JNK pathways, which results in increased expression of c-Fos, c-Jun, or both, has been reported in some chemically treated cells (Chang et al., 2009). Moreover, ERK transfers signals to the nuclei to induce proliferation and differentiation, by stimulating the transcription factors that induce expression of c-Fos and other compounds (Lopez-Ilasaca, 1998).

Activator protein-1 in the nucleus is influenced by the cellular redox status and is thought to play important roles in proinflammatory and carcinogenic events (Lee and Lim, 2011). It was reported to regulate expression of cyclooxygenase-2 (COX-2) and iNOS proinflammatory factors (Lee and Lim, 2011). In addition, AP-1 activation is induced at multiple levels by MAPK activation involving the major pathways of ERK and
JNK (Shen et al., 2006). In many studies, Cd induced overexpression of c-Fos and c-Jun transcription factors (Bertin and Averbeck, 2006; Yang et al., 2007). In the current study, AP-1 was activated in response to $\mathrm{Cd}$ but inhibited by pretreatment with L67 protein in the presence of Cd (Figure 8).

Based on the experimental findings, we made the following assumptions. The possible mechanism of cell proliferation inhibition by L67 protein is that the extract first inhibits calcium mobilization and depresses translocation of PKC. Subsequently, the signals ERK, JNK, and AP-1, which are located downstream of PKC, were not activated by $\mathrm{L} 67$ protein.

Two possible mechanisms might explain protection from Cd-induced carcinogenesis of RAW 264.7 cells by L67 protein. First, L67 protein might have negatively charged AA residues that stimulate survival signal or increase bioactivity of RAW 264.7 cells. Negatively charged AA of L67 have high polarity and high protein moiety, which cause the protein to interact with the receptor on the membrane of RAW 264.7 cells. The result of this interaction is stimulation of signal-related kinases in the intracellular plasm. Then, the stimulated
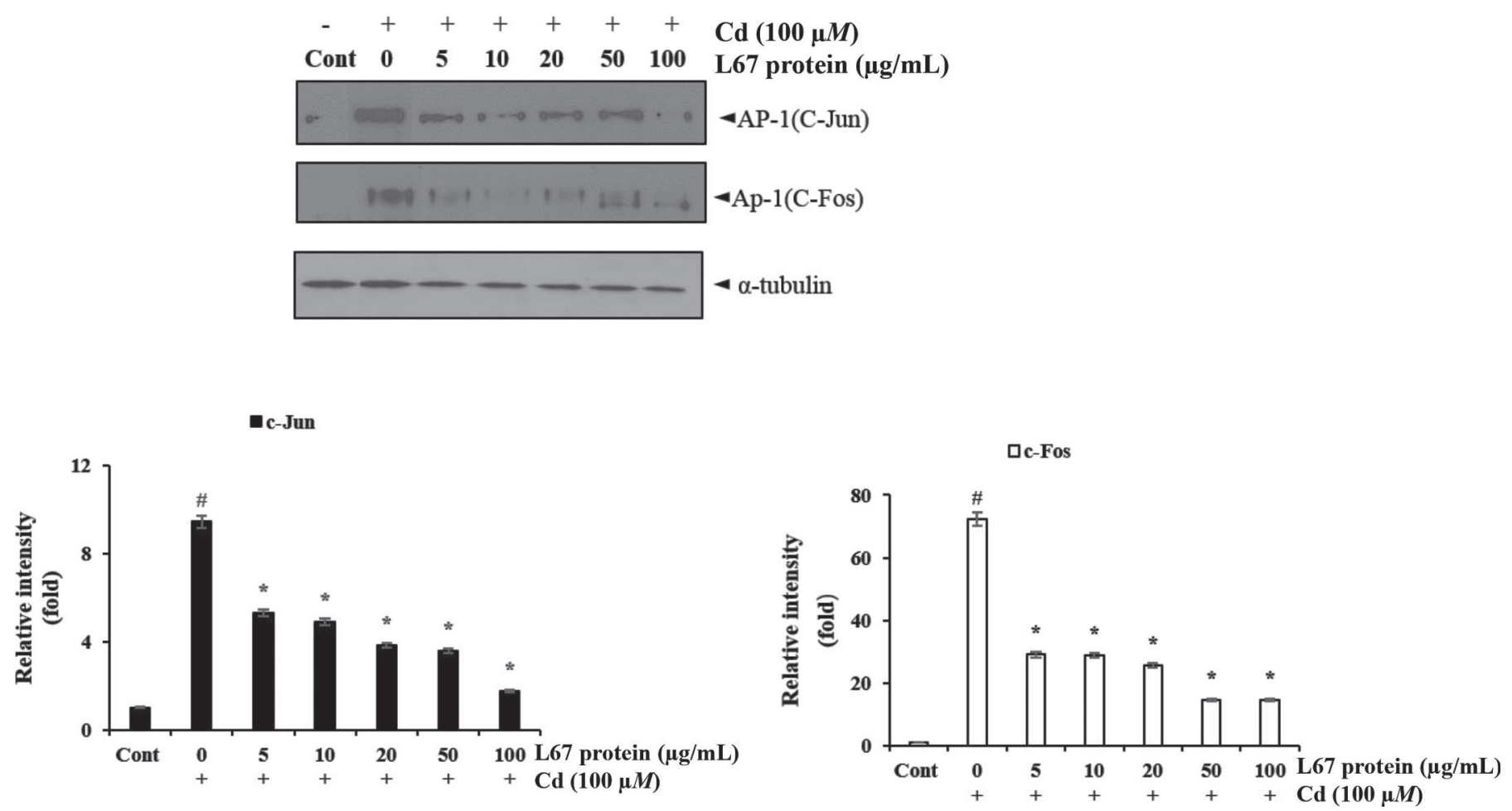

Figure 8. Inhibitory effect of L67 protein from Lactobacillus plantarum on the transcriptional factor activator protein (AP-1; c-Jun and cFos) in Cd-treated RAW 264.7 cells. The cells were treated with $\mathrm{Cd}(100 \mu M)$ for $3 \mathrm{~h}$ in the absence or pretreatment of L67 protein $(5,10,20$, 50 , and $100 \mu \mathrm{g} / \mathrm{mL}$ ). The relative intensities of bands were calculated with Scion Imaging Software (Scion Image Beta 4.02; Scion, Frederick, $\mathrm{MD})$. Data were represented as absolute intensities and expressed as means \pm SE from triplicates $(\mathrm{n}=9)$. \#Significant difference between the treatment and control groups $(P<0.05)$; *significant difference between Cd treatment and L67 protein in the presence of Cd $(P<0.05)$. Cont $=$ control. 
kinase transfers the signal to survival or bioactivity. Second, the L67 protein interacts with the positive divalent cation of cadmium and then builds a complex compound before transit to the cell membrane.

In conclusion, we showed that pretreatment with L67 protein inhibits cytotoxicity and intracellular $\mathrm{Ca}^{2+}$ mobilization following exposure of RAW 264.7 cells to cadmium chloride. Pretreatment with L67 protein also significantly suppressed the expression of AP-1 (C-fos and C-jun) and MAPK (ERK and JNK). These findings suggest that L67 protein might protect against inflammation caused by the cadmium ions naturally present in food. In addition, L. plantarum L67 can be used as a starter culture strain with a potential protective effect against cadmium toxicity.

\section{ACKNOWLEDGMENTS}

This work was completely financed by iPET (Korea Institute of Planning and Evaluation for Technology in Food, Agriculture, Forestry and Fisheries; Republic of Korea) in 2014. The authors declare that they have no conflicts of interest.

\section{REFERENCES}

Batiza, A. F., T. Schulz, and P. H. Masson. 1996. Yeast respond to hypotonic shock with a calcium pulse. J. Biol. Chem. 271:2335723362 .

Bertin, G., and D. Averbeck. 2006. Cadmium: Cellular effects, modifications of biomolecules, modulation of DNA repair and genotoxic consequences (a review). Biochimie 88:1549-1559.

Bradford, M. M. 1976. A rapid and sensitive method for the quantitation of microgram quantities of protein utilizing the principle of protein-dye binding. Anal. Biochem. 72:248-254.

Buchauer, M. J. 1973. Contamination of soil and vegetation near a zinc smelter by zinc, cadmium, cooper, and lead. Environ. Sci. Technol. 7:121-135.

Chang, C. H., F. Y. Yu, L. T. Wang, Y. S. Lin, and B. H. Liu. 2009 Activation of ERK and JNK signaling pathways by mycotoxin citrinin in human cells. Toxicol. Appl. Pharmacol. 237:281-287.

Chang, L., and M. Karin. 2001. Mammalian MAP kinase signalling cascades. Nature 410:37-40.

Chen, S., Y. Xu, B. Xu, M. Guo, Z. Zhang, L. Liu, H. Ma, Z. Chen, Y. Luo, S. Huang, and L. Chen. 2011. CaMKII is involved in cadmium activation of MAPK and mTOR pathways leading to neuronal cell death. J. Neurochem. 119:1108-1118.

Cheung, W. Y. 1988. Calmodulin and its activation by cadmium ion. Ann. N. Y. Acad. Sci. 522:74-87.

Chung, W. Y., J. H. Park, M. J. Kim, H. O. Kim, J. K. Hwang, S. K. Lee, and K. K. Park. 2007. Xanthorrhizolinhibits 12-Otetradecanoylphorbol-13-acetate-induced acute inflammation and two-stage mouse skin carcinogenesis by blocking the expression of ornithine decarboxylase, cyclooxygenase- 2 and inducible nitric oxide synthase through mitogen-activated protein kinases and/or the nuclear factor-kappa B. Carcinogenesis 28:1224-1231.

Dobkin-Bekman, M., L. Rahamin Ben-Navi, B. Shterntal, L. Sviridonov, F. Przedecki, M. Naidich-Exler, C. Brodie, R. Seger, and Z. Naor. 2010. Differential role of PKC isoforms in GnRH and phorbol 12-myristate 13-acetate activation of extracellular signal-regulated kinase and Jun N-terminal kinase. Endocrinology 151:4894-4907.
Fernández, M., J. A. Hudson, R. Korpela, and C. G. de Los ReyesGavilán. 2015. Impact on human health of microorganisms present in fermented dairy products: An overview. BioMed Res. Int. 2015:412714.

Fowler, B. A., G. F. Nordberg, M. Nordberg, and L. Friberg. 2011 Chapter 23: Cadmium. Pages 446-470 in Handbook on the Toxicology of Metals. 3rd ed. G. F. Nordberg, B. A. Fowler, M. Nordberg, and L. Friberg, ed. Academic Press, Burlington, MA.

Halttunen, T., M. C. Collado, H. El-Nezami, J. Meriluoto, and S. Salminen. 2008. Combining strains of lactic acid bacteria may reduce their toxin and heavy metal removal efficiency from aqueous solution. Lett. Appl. Microbiol. 46:160-165.

Hong, Y. F., H. Kim, H. R. Kim, M. G. Gim, and D. K. Chung. 2014 Different immune regulatory potential of Lactobacillus plantarum and lactobacillus sakei isolated from Kimchi. J. Microbiol. Biotechnol. 24:1629-1635.

Ito, Y., Y. Sasaki, M. Horimoto, S. Wada, Y. Tanaka, A. Kasahara, T. Ueki, T. Hirano, H. Yamamoto, J. Fujimoto, E. Okamoto, N Hayashi, and M. Hori. 1998. Activation of mitogen-activated protein kinases/extracellular signal-regulated kinases in human hepatocellular carcinoma. Hepatology 27:951-958.

Jãrup, L., M. Berglund, C. G. Elinder, G. Nordberg, and M. Vahter 1998. Health effects of cadmium exposure - A review of the literature and a risk estimate. Scand. J. Work Environ. Health 24(Suppl. 1):1-51.

Johnson-Henry, K. C., K. E. Hagen, M. Gordonpour, T. A. Tompkins, and P. M. Sherman. 2007. Surface-layer protein extracts from Lactobacillus helveticus inhibit enterohaemorrhagic Escherichia coli O157:H7 adhesion to epithelial cells. Cell. Microbiol. 9:356-367.

Kim, E. K., and E. J. Choi. 2010. Pathological roles of MAPK signaling pathways in human diseases. Biochim. Biophys. Acta 1802:396-405.

Kim, S.D., C. K. Moon, S. Y. Eun, P. D. Ryu, and S. A. Jo. 2005. Identification of ASK1, MKK4, JNK, c-Jun, and caspase-3 as a signaling cascade involved in cadmium-induced neuronal cell apoptosis. Biochem. Biophys. Res. Commun. 328:326-334.

Kimata, M., M. Shichijo, T. Miura, I. Serizawa, N. Inagawi, and H. Nagai. 1999. $\mathrm{Ca}^{2+}$ and protein kinase $\mathrm{C}$ signaling for histamine and sulfidoleukotrienes released from human cultured mast cells. Biochem. Biophys. Res. Commun. 257:895-900.

Konstantinov, S. R., H. Smidt, W. M. de Vos, S. C. Bruijns, S. K Singh, F. Valence, D. Molle, S. Lortal, E. Altermann, T. R. Klaenhammer, and Y. van Kooyk. 2008. S layer protein A of Lactobacillus acidophilus NCFM regulates immature dendritic cell and T cell functions. Proc. Natl. Acad. Sci. USA 105:19474-19479.

Kouzarides, T., and E. Ziff. 1988. The role of the leucine zipper in the fos-jun interaction. Nature 336:646-651.

Kruger, M. C., A. Fear, W.-H. Chua, G. G. Plimmer, and L. M. Schollum. 2009. The effect of Lactobacillus rhamnosus HN001 on mineral absorption and bone health in growing male and ovariectomised female rats. Dairy Sci. Technol. 89:219-231.

Lee, J., and K. T. Lim. 2011. Preventive effect of phytoglycoprotein $(27 \mathrm{kDa})$ on inflammatory factors at liver injury in cadmium chloride-exposed ICR mice. J. Cell. Biochem. 112:694-703.

Lopez-Ilasaca, M. 1998. Signaling from G-protein-coupled receptors to mitogen-activated protein (MAP)-kinase cascades. Biochem. Pharmacol. 56:269-277.

Lowry, O. H., N. J. Rosebrough, A. L. Farr, and R. J. Randall. 1951. Protein measurement with the folin phenol reagent. J. Biol. Chem. 193:265-275.

McConnell, J. R., and R. Edwards. 2008. Coal burning leaves toxic heavy metal legacy in the Arctic. Proc. Natl. Acad. Sci. USA 105:12140-12144.

Mrvcic, J., D. Stanzer, V. Bacun-Druzina, and V. Stehlik-Tomas. 2009. Copper binding by lactic acid bacteria (LAB). Biosci. Microflora 28:1-6.

Nair, A. R., O. Degheselle, K. Smeets, E. Van Kerkhove, and A. Cuypers. 2013. Cadmiuminduced pathologies: Where is the oxidative balance lost (or not)? Int. J. Mol. Sci. 14:6116-6143.

Nakashima, S. 2002. Protein kinase C alpha (PKC alpha): regulation and biological function. J. Biochem. 132:669-675. 
Neville, D. M. Jr., and H. Glossmann. 1974. Molecular weight determination of membrane protein and glycoprotein subunits by discontinuous gel electrophoresis in dodecyl sulfate. Methods Enzymol. 32:92-102.

Oh, P. S., and K. T. Lim. 2008. Blocking of intracellular ROS production by phytoglycoprotein $(30 \mathrm{kDa})$ causes anti-proliferation in bisphenol A stimulated Chang liver cells. J. Appl. Toxicol. 28:749-758.

Olsson, I. M., I. Bensryd, T. Lundh, H. Ottosson, S. Skerfving, and A. Oskarsson. 2002. Cadmium in blood and urine: Impact of sex, age, dietary intake, iron status, and former smoking-Association of renal effects. Environ. Health Perspect. 110:1185-1190.

Patton, W. F., M. R. Dhanak, and B. S. Jacobson. 1989. Differential partitioning of plasma membrane proteins into the triton $\mathrm{X}$ 100-insoluble cytoskeleton fraction during concanavalin A-induced receptor redistribution. J. Cell Sci. 92:85-91.

Ramirez, D. C., and M. S. Gimenez. 2003. Induction of redox changes, inducible nitric oxide synthase and cyclooxygenase-2 by chronic cadmium exposure in mouse peritoneal macrophages. Toxicol. Lett. 145:121-132.

Rhee, C. H., and H. D. Park. 2001. Three glycoproteins with antimutagenic activity identified in Lactobacillus plantarum KLAB21. Appl. Environ. Microbiol. 67:3445-3449.

Roderick, H. L., and S. J. Cook. 2008. $\mathrm{Ca}^{2+}$ signalling checkpoints in cancer: Remodelling $\mathrm{Ca} 2+$ for cancer cell proliferation and survival. Nat. Rev. Cancer 8:361-375.

Saha, J. K., N. R. Panwar, and M. V. Singh. 2010. Determination of lead and cadmium concentration limits in agricultural soil and municipal solid waste compost through an approach of zero tolerance to food contamination. Environ. Monit. Assess. 168:397-406.

Satarug, S., S. H. Garrett, M. A. Sens, and D. A. Sens. 2011. Cadmium, environmental exposure, and health outcomes. Cien. Saude Colet. 16:2587-2602. http://dx.doi.org/10.1590/S141381232011000500029

Scholz-Ahrens, K. E., P. Ade, B. Marten, P. Weber, W. Timm, Y. Avarsigmail, C. C. Glüer, and J. Schrezenmeir. 2007. Prebiotics, probiotics, and synbiotics affect mineral absorption, bone mineral content, and bone structure. J. Nutr. 137:838S-846S.
Shen, F., X. Fan, B. Liu, X. Jia, H. Du, B. You, M. Ye, C. Huang, and X. Shi. 2006. Overexpression of cyclin D1-CDK4 in silica-induced transformed cells is due to activation of ERKs, JNKs/AP-1 pathway. Toxicol. Lett. 160:185-195.

Song, M., B. Yun, J. K. Moon, D. J. Park, K. Lim, and S. Oh. 2015a. Characterization of selected Lactobacillus strains for use as probiotics. Korean J. Food Sci. Anim. Resour. 35:551-556.

Song, S., D. W. Bae, K. Lim, M. W. Griffiths, and S. Oh. 2014. Cold stress improves the ability of lactobacillus plantarum L67 to survive freezing. Int. J. Food Microbiol. 191:135-143.

Song, S., S. Oh, and K. T. Lim. 2015b. The proteins $(12$ and $15 \mathrm{kDa})$ isolated from heat-killed Lactobacillus plantarum L67 induces apoptosis in HT-29 cells. Cell Biochem. Funct. 33:89-96.

Thévenod, F., and W. K. Lee. 2013. Cadmium and cellular signaling cascades: Interactions between cell death and survival pathways. Arch. Toxicol. 87:1743-1786.

Tzirogiannis, K. N., G. I. Panoutsopoulos, M. D. Demonakou, R. I. Hereti, K. N. Alexandropoulou, A. C. Basayannis, and M. G. Mykoniatis. 2003. Timecourse of cadmium-induced acute hepatotoxicity in the rat liver: The role of apoptosis. Arch. Toxicol. 77:694-701.

Wang, B., J. L. Xiao, Y. H. Ling, X. J. Meng, B. Wu, X. Y. Yang, and F. Zou. 2014. BNIP3 upregulation by ERK and JNK mediates cadmium-induced necrosis in neuronal cells. Toxicol. Sci. 140:393-402

Yang, Z., S. Yang, S. Y. Qian, J. S. Hong, M. B. Kadiiska, R. W. Tennant, M. P. Waalkes, and J. Liu. 2007. Cadmium-induced toxicity in rat primary mid-brain neuroglia cultures: Role of oxidative stress from microglia. Toxicol. Sci. 98:488-494.

Zhai, Q., G. Wang, J. Zhao, X. Liu, A. Narbad, Y. Q. Chen, H. Zhang, F. Tian, and W. Chen. 2014. Protective effects of Lactobacillus plantarum CCFM8610 against chronic cadmium toxicity in mice indicate routes of protection besides intestinal sequestration. Appl. Environ. Microbiol. 80:4063-4071.

Zheng, L. P., D. L. Zhang, J. Huang, L. Q. Xu, A. X. Xu, X. Y. Du, D. F. Tang, and Y. H. Zheng. 2010. Proto-oncogene c-erbB2 initiates rat primordial follicle growth via PKC and MAPK pathways. Reprod. Biol. Endocrinol. 8:66. 